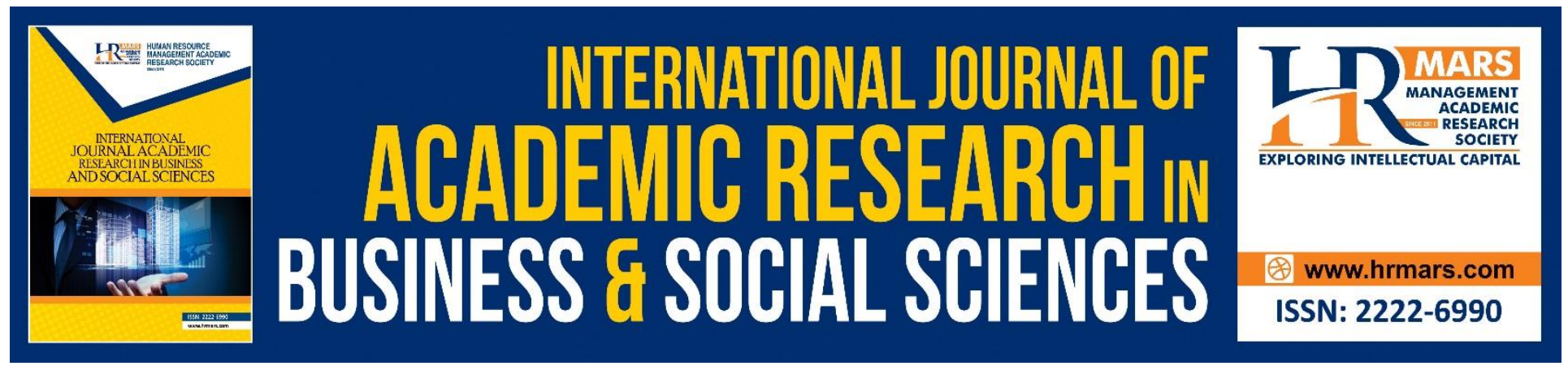

\title{
Halal Food Supply Chain Implementation Model: A Measurement Development and Validation
}

\author{
Wan Marhaini Wan Omar, Shams Rahman
}

To Link this Article: http://dx.doi.org/10.6007/IJARBSS/v8-i11/5566

DOI: $10.6007 /$ IJARBSS/v8-i11/5566

Received: 07 Nov 2018, Revised: 26 Nov 2018, Accepted: 12 Dec 2018

Published Online: 14 Dec 2018

In-Text Citation: (Omar \& Rahman, 2018)

To Cite this Article: Omar, W. M. W., \& Rahman, S. (2018). Halal Food Supply Chain Implementation Model: A Measurement Development and Validation. International Journal of Academic Research in Business and Social Sciences, 8(11), 2029-2043.

Copyright: () 2018 The Author(s)

Published by Human Resource Management Academic Research Society (www.hrmars.com)

This article is published under the Creative Commons Attribution (CC BY 4.0) license. Anyone may reproduce, distribute, translate and create derivative works of this article (for both commercial and non-commercial purposes), subject to full attribution to the original publication and authors. The full terms of this license may be seen

at: http://creativecommons.org/licences/by/4.0/legalcode

\section{Vol. 8, No. 11, 2018, Pg. 2029 - 2043}

Full Terms \& Conditions of access and use can be found at http://hrmars.com/index.php/pages/detail/publication-ethics 


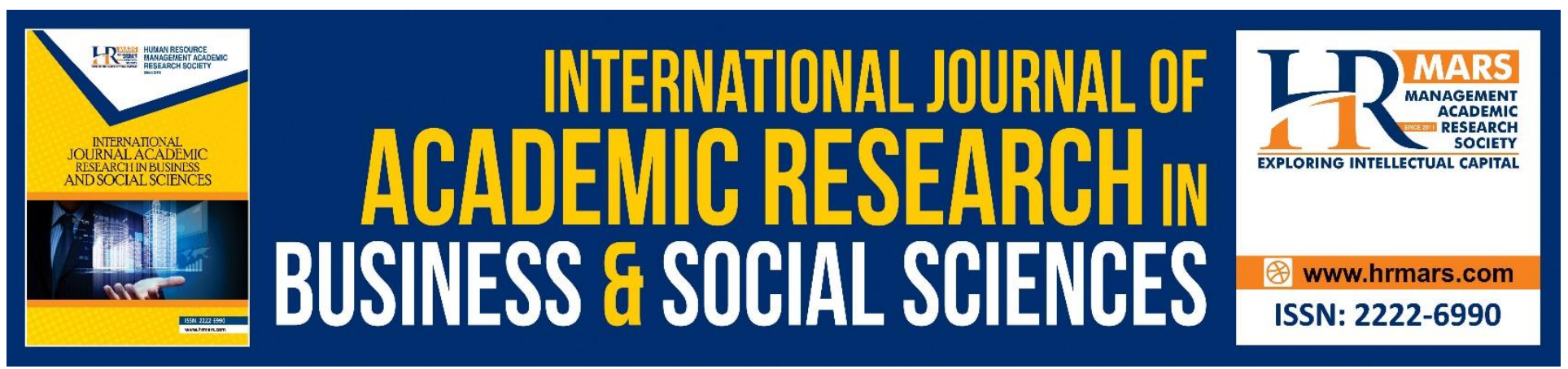

\title{
Halal Food Supply Chain Implementation Model: A Measurement Development and Validation
}

\author{
Wan Marhaini Wan Omar ${ }^{1}$, Shams Rahman² \\ ${ }^{1}$ Faculty of Business and Management, Universiti Technologi MARA Kelantan \\ Kampus Kota Bharu Lembah Sireh, 15050 Kota Bharu, Kelantan, Malaysia \\ Email: whaini299@kelantan.uitm.edu.my \\ ${ }^{2}$ School of Business IT \& Logistics, College of Business, RMIT University \\ 445 Swanston Street, Melbourne 3000, Australia
}

Email: Shams.rahman@rmit.edu.my

\begin{abstract}
The global demand for halal food products is growing throughout the world. However, research in halal food supply chain is relatively new. This study is conducted to develop and validate a measurement instrument for the halal food supply chain (HFSC) implementation model and confirms it as a higher-order construct. The measurement items of the dimensions used in the model are developed and validated based on a comprehensive multi-step approach prior to the large-scale survey. A questionnaire-based survey is distributed to 600 Malaysian halal certified food and beverage organisations. A total of 240 usable questionnaires are collected to confirm the underlying dimensions empirically. Confirmatory factor analysis is conducted to define the model of HFSC implementation and to confirm the HFSC implementation as a higher-order construct. The results revealed that nine dimensions are crucial and significantly define HFSC implementation as a higherorder construct. To our knowledge this is the first attempt to develop and validate the measurement instrument for HFSC implementation model. Theoretically this study contributes to the body of knowledge in defining and confirming the HFSC implementation as a higher-order construct. Furthermore, it provides a valid measurement instrument for further halal research in the context of other countries and markets.
\end{abstract}

Keywords: Halal, Halal Food Supply Chain, Processed Food and Beverages

\section{INTRODUCTION}

Over the last ten years the management of halal food supply chain has become a new research domain within the broader food supply chain management. Halal can be defined as an act or product that is lawful and permitted (Al-Qaradawi, 2007). The concept of halal food is not limited to meat and poultry but also includes processed food, dairy products, food ingredients and even non-food 
products. By any estimate the market for halal products is huge and growing fast. For example, in 2014, the global halal food and beverage expenditure increased by US\$1.128 billion which is an increase of 4.3\% compared to the expenditure in 2013 (Thomson Reuters, 2015).

The rapid increase in halal food business is not only due to the growth and spread of Muslim population globally, but also due to the growth of halal consumers in the non-Muslim regions such as Europe, North America and China. This had made halal food market segment is bigger in size and potentially competitive.

In the context of supply chain process, halal food is said to be vulnerable since many major cases were reported globally relating to the issues of authenticity, adulteration and fraudulent halal logo. The issues have been a controversial and much disputed subject within the field of halal food industry as reported by (Tieman et al., 2012; Bonne and Verbeke, 2008; and Fadzlillah et al., 2011). The authenticity issue is concern whether the materials involved in halal food products have been mixed intentionally with cheaper non-halal materials. For instance, few years ago, two flavors of halal certified dairy milk chocolates manufactured in Malaysia were found to contain porcine DNA (Jaques, 2015). Apart from that, the image of the halal food industry also has been tarnished by the rising issues of fraudulent halal logo and cross-contamination with non-halal products as confirmed by Norman et al., (2008) and Mohd Albakir \& Mohd-Mokhtar, (2011). Furthermore, there is a concern amongst the halal consumers whether the halal status of food products can be guaranteed throughout the supply chain since halal products are now sourced from various parts of the world including non-Muslim countries. The possibility of cross-contamination with non-halal products at various critical points throughout the supply chain process is considerable. As such, these issues have heightened the need for halal food supply chain (HFSC) implementation model so that trust and credibility can be delivered to the relevant consumers.

The increasing trend of research in halal food management has attained the attention of researchers and practitioners a decade ago. In a recent review of research on halal food management, Wan Omar et al. (2015) concludes that research focusing on HFSC implementation is lack of theoretical foundation and relatively under-researched. Despite the number of research has been done in different aspects of halal food management, developing a comprehensive model of HFSC implementation in Malaysia is yet to be done. Prior studies have focused mainly on consumer studies such as consumer awareness of halal products, purchasing behavior of Muslim consumers, product adoption, and branding as in agreement with Shah Alam \& Mohamed Sayuti, (2011), Wan Omar et al., (2008) and Wilson \& Liu, (2010). In addition, the review found that there has been little effort made on developing and validating an instrument that measures HFSC. Hence, a rigorous validated instrument is needed for researchers to be able to test the causal relationship among implementations and performance outcomes.

Taking a holistic view of halal and considering multiple dimensions of halalness, this study develops and validates a measurement instrument for HFSC implementation. More specifically, this research develops and validates a measurement instrument for HFSC implementation that can be used for future researchers in HFSC. The research findings provide in-depth understandings of the 
dimensions of HFSC implementation model which can be used as a comprehensive reference system by the Malaysian halal-certified manufacturers and policy-makers to develop appropriate strategies for the halal food supply chain management.

The rest of the paper is structured as follows. The next section presents a brief review of related literature on the constructs of halal food supply chain and proposed a conceptual framework. Then it provides the research methodology section, followed by a section on data analysis of largescale survey and confirmatory factor analysis. The following section discusses the major findings, and the research implications are discussed right after that. Finally, the paper concludes with future research directions and limitations.

\section{DEVELOPING DIMENSIONS FOR HFSC IMPLEMENTATION MODEL}

Using a systematic review of halal food management literature and supported by the conventions theory as the theoretical foundation, eleven dimensions were identified to define halal food supply chain (HFSC) implementation model. From this review, a number of hypotheses can be developed. Detailed descriptions of the dimensions and development of hypotheses are presented in the following paragraphs.

In halal food supply chain, it needs to be clean and halal from farm to fork. Islamic teachings have emphasized the concept of cleanliness not only in terms of clothing, building and its surrounding area as stated by Abdul Rahim (2005), but also in food (Riaz \& Chaudry, 2004). The organization shall use food grade cleaning chemicals for cleaning usage and disposed the contaminated prepared food based on local disposal regulations and Shariah requirements.

Food safety is of prime importance to consumers and professionals in the food sectors. Halal food manufacturers should not only focus on Islamic processing techniques, but also on the safety and quality for both products and processes (Talib et al., 2008). Otherwise, failure to secure the food will lead to food spoilage which considered as wasteful, costly and can affect trade and consumer confidence (Aung and Chang, 2014).

One of the most important aspects of a Muslim's life is food and dietary code as revealed in the Quran and recorded in the Hadith (compilation of the traditions of the Prophet Muhammad) and these constitute the two major sources of Islamic dietary law. By referring the Islamic dietary law, manufacturers may avoid using the food ingredients that do not meet dietary standards. Furthermore, A Muslim who adheres to the Islamic dietary law is a symbol of faith towards his or her religion, and they should avoid foods that do not meet their dietary standards.

In the manufacture of halal products, it is imperative that all possible sources of contamination are eliminated throughout the entire production chain as stated by Riaz and Chaudry (2004). During the processing stage, Ali et al. (2014) and Nakyinsige et al. (2012) are in agreement that halal products must be physically segregated from non-halal products to prevent crosscontamination. Several studies such as Tieman (2011) and Lodhi (2009) have pointed out the need to physically segregate halal products to prevent any intentionally or unintentionally, direct contact with elements that can defect the halal status.

To facilitate halal food segregation, Lodhi (2009) and Ab Talib et al. (2014) highlighted the need for dedicated infrastructure to transport, store and market halal products. Dedicated infrastructure such as a transport, warehouses and storage places, and handling equipment, minimise 
the possibility of halal products being mixed with non-halal products. In other words, devices, utensils, machines and processing aids used for processing halal food shall be designed and constructed only for halal food [23]. If the equipment and machines which were previously used or in contact with prohibited Najs, it need to be washed and ritually cleansed as required by Shariah law.

According to Ab Talib and Mohd Johan (2012), the process of packaging and labeling products must also be considered to create a genuine and wholesome halal product. Soong (2007) suggests that food packaging must not be made from non-halal substance and if it makes from raw material of animal origin, then required proper halal certification. In food labelling, disguising any facts such as sources of the ingredients is prohibited in Islamic jurisprudence (Ab Talib et al., 2014).

The ethical component reflects on the development of a halal product which therefore, must be consistent with Shariah principles. In the literature, researchers identify the ethical features as being environmentally friendly, considering animals' welfare, having an organic character, respectful Islamic financing and fair trade attributes (Mohamad and Hassan, 2011). Al-Qaradawi (2007) emphasis that the principle of permissibility where it is not only limited to the things and objects being used but also includes all human actions and behaviours. According to Irfan (2010), having ethical producers who are practically involved in fair trade and are socially responsible within the whole production chain do constitutes a major concern in the halal industry.

Management needs to be capable in providing evidence of its commitment to the implementation of the halal products by giving enough training to staff, capable to innovate and have sufficient resources. To develop a sustainable pool of knowledge workers and professionals in the halal industry, training is essential and management should be able to ensure everyone is appropriately trained (Tieman et al., 2012) and (Ali et al., 2014). Organizations have to ensure that workers are aware and understand the halal requirements in order to minimize the probabilities of human error in the production of halal products.

Furthermore, in the halal food industry context, management needs to involve in innovation such as venturing in the development of a halal traceability and tracking system management and Zailani et al. (2010) believes that be innovative can improve halal transparency in the production and over the entire supply chain. This was proven from the study by Yang and Bao (2011) that used the integrated application of the RFID, barcode, GSM technology and Internet technology to trace the halal quality of the beef products and to establish a critical information database for halal beef products' quality.

In the halal food industry, management must ensure the availability of resources, such as the workforce, infrastructure, machinery and equipment and financial capital before halal production is fully operational (Standards Malaysia, 2009). It is important for the organisation to provide and maintain the infrastructure needed to achieve conformity to product requirements, which includes: (i) buildings, workspace, prayer room, ablution facilities and other associated utilities for Muslims; (ii) hardware and software equipment; (iii) supporting services, and; (iv) the eateries within the premise of the organisation shall provide halal foods and beverages. This is important to ensure the smooth running of the halal business.

Based on this conceptualisation of the HFSC implementation model as having the dimensions of cleanliness, safety, Islamic dietary law, physical segregation, material handlings, storage and 
transport, packaging and labelling, ethical practices, training and personnel, resource availability and innovative capability, the following hypotheses is proposed:

$H_{1 a-k}$ : Halal food supply chain implementation is positively defined by (a) cleanliness, (b) safety, (c) Islamic dietary law, (d) physical segregation, (e) material handlings, (f) storage and transport, (g) packaging and labelling, (h) ethical practices, (i) training and personnel, (j) innovative capability and (k) resource availability.

\section{METHODOLOGY}

Halal food supply chain studies have predominantly been case studies (Omar and Jaafar, 2011; Tieman et al., 2012; and Ali et al., 2014). Within the context of the quantitative method category, a vast majority of research in halal food supply chain employ either descriptive statistics or regression as presented by Wan Omar et al. (2015). This study seeks to develop the scales, refine and validate the measures using the survey instrument in processed foods and beverages industry sector in Malaysia. The development and validation process is adopted based on a comprehensive multi-step approach suggested by Shah and Ward (2007). Each of these processes is described below.

\section{Scale Development and Content Validity}

Items to measure the construct of halal food supply chain (HFSC) implementation were generated using several approaches. First, the items were adapted from a list of potential validated items from the past literature in halal studies and food supply chain management. The second approach is where the items were taken through an extensive review of literature and inputs from industrial experts. As a result, a pool of new items was developed to measure HFSC implementation. An initial pool of new items was sorted and modified in an interpretive process by the researchers. Then, the items were categorised according to the underlying dimensions. Based on the identified dimensions, a preliminary set of 52 items for measuring HFSC implementation is developed. These items were operationalised using Likert scales anchored by 1 (strongly disagree) and 7 (strongly agree).

To assess the content validity of the measurement items, it is suggested that the survey need to be reviewed as a representative by the expert evaluation (Netemeyer et al., 2003). Thus, a pretest was conducted with two industrial experts and two academics to assess for the content validity assessment. These experts are chosen based on their vast experience in the halal industry specifically in halal food and beverage industry sector. The experts targeted from a group of management people such as directors, senior executives and managers. Both of the industrial experts are from leading halal food organisations which have been operating more than 25 years and their products have been certified halal for more than 10 years. The academic experts possess strong background in halal studies and supply chain management respectively. With these background, they were qualified enough to be the expert assessor for this study's instrument. Feedback has been obtained from experts and both the authors discussed the feedbacks and suggestions. Items which are not clearly measure the actual context of the HFSC implementation were advised to be rephrased. 


\section{Pilot Study}

After responding to the expert panels and refining the survey instrument, a pilot study was administered to the certified halal organizations in Malaysia's processed foods and beverages industry sector. The questionnaires were distributed during the Penang International Halal Expo and Conference 2015 (PIHEC 2015), and the respondents are randomly selected from the conference directory. They were approached face-to-face and a copy of survey questionnaire was given to them who agreed to complete and provide feedback. The completed questionnaires were collected the next day at the agreed time. 120 questionnaires were distributed that event and 100 completed questionnaires were collected personally from the identified respondents who are willing to participate in the survey. Internal consistency of the items was assessed using the reliability test. Reliability test were computed using Cronbach's alpha. The results of the dimensions are varied between 0.730 and 0.902 , and with the value of 0.7 or greater all the values are within the acceptable thresholds and suggesting reliability (Nunnally and Bernstein, 1994).

Assessment of Dimensionality using Exploratory Factor Analysis (EFA)

Exploratory factor analysis (EFA) was performed to assess the factor structure and dimensionality. In this study, EFA was employed since there is no existing theory and framework regarding the existence of dimensions in HFSC implementation as a higher-order construct. Thus, this study represents an initial empirical work on proposing the dimensions of HFSC implementation. The subsequent factors derived from EFA are the starting point for the confirmatory analysis (CFA). EFA was conducted using principal component analysis (PCA) with varimax rotation to extract the factors. The pilot test $(n=100)$ data were used as a choice of data set to run this analysis. Ten-factor solutions resulted with reasonable loadings corresponding to the proposed dimensions. Results show the eigenvalues greater than 1.0 and the total variance explained is $70.5 \%$ which is acceptable (Hair et al., 2010). KMO, a measure of sampling adequacy, found to be 0.890 , indicating sufficient intercorrelations while Bartlett's Test of Sphericity found significant $(p<0.01)$. Further, all the factor loading scores are higher than 0.50 (Hair et al., 2010). The results indicate that the scale is unidimensional and factorial distinct. Therefore, questionnaire was revised and ten-factors are retained for the main survey.

\section{Main Survey}

In Malaysia, a total of 600 structured questionnaires were distributed to selected halal certified food and beverage organisations. By using the drop-and-collect method, respondents are identified and contacted personally, prior to dropping off the questionnaires. The completed questionnaires are then personally collected by the researcher. In the end, 240 organisations participated in this research, yielding the effective response rate of $40 \%$. Data collected from three states and one federal territory in Malaysia. Since more than $60 \%$ of halal certified companies are located in these areas, the choice of these areas is legitimate. The final version of the questionnaire is translated into Malay by a certified linguistic specialist. The actual data is screened to check whether data are correctly entered, missing values, free outliers, and to confirm that the distribution of the variables is normal. Then, the confirmatory factor analysis (CFA) approach is employed to verify the structure of the measurement models. 


\section{RESULTS}

Of all respondents, $30.4 \%$ were managers followed by owner (27.1\%). Most respondents have completed graduate studies (51.7\%) and 72 of the respondents had diploma. Approximately $32.1 \%$ indicated that they have been working in the organization for between 6 and 10 years, followed by $30 \%$ had worked for 5 years or less. Of 240 respondents, most (36.9\%) had between 6 to 10 years of managerial experience in the halal food and beverage industry sector and. It is evident that the majority of respondents had experienced in the halal food and beverage industry. Regarding the responding organizations, 123 were medium-sized enterprises (51.2\%) with between 75 to 200 employees, followed by small-sized enterprises (34.6\%) with between 5 to 74 employees. Only 40 organizations have operated for more than 25 years, the most (35.8\%) had between 6 to 15 years.

Assessment of first-order measurement model for HFSC implementation using Confirmatory Factor Analysis (CFA)

The measurement model of each construct is tested by a confirmatory factor analysis using covariance based software called IBM SPSS Amos 22. The measurement model of halal food supply chain (HFSC) implementation is analysed using ten proposed first-order constructs (C, S, ID, PS, ST, $P L, E P, T P, I C$ and RA). At the first-order level, forty-four items were used to measure all the ten dimensions subjected to a CFA. The assessment of the measurement model started with the examination of standardized residuals covariance. There were few items had residual values greater than the threshold of 2.58 as suggested by (Hair et al., 2010) and needed to be deleted. At the same times, modification indices (MI) also showed that similar items had large values. Regardless of factor loadings above 0.6, MI needs to be examined, particularly in the case where the fitness indices do not achieve the required level (Awang, 2015). In MI, it shows the correlated error among the items where two or more items are redundant to each other. The relevant items were removed iteratively until the most significant fit model is achieved. The process resulted in deleting 10 items and one factor from the measurement model due to high $\mathrm{Ml}$ and model fit problem. These deletions do not change the content of HFSC implementation. The remaining items are still significant in measuring the first-order measurement model of HFSC implementation. 
INTERNATIONAL JOURNAL OF ACADEMIC RESEARCH IN BUSINESS AND SOCIAL SCIENCES Vol. 8, No. 11, Nov, 2018, E-ISSN: 2222-6990 @ 2018 HRMARS

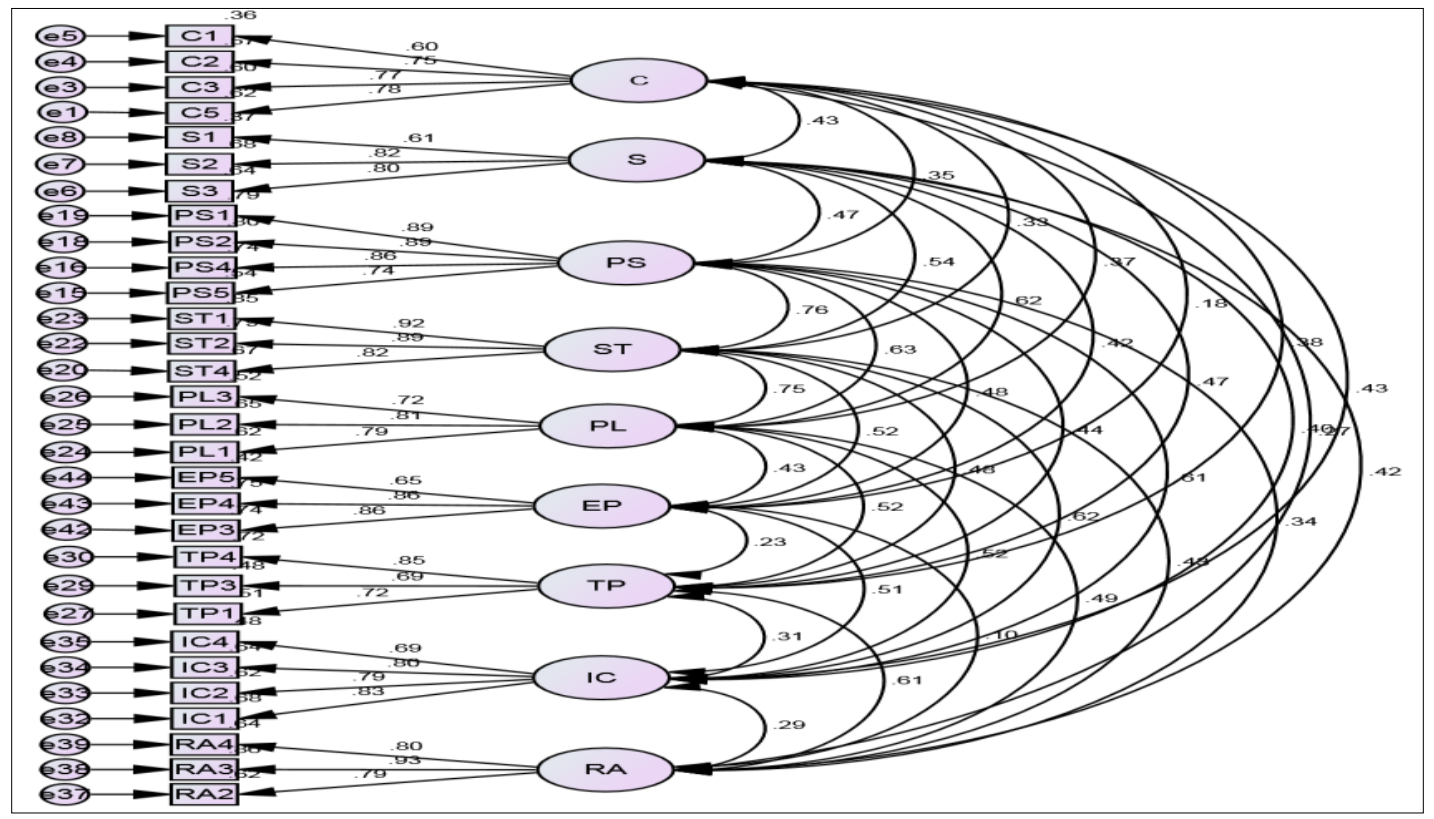

Notes: C-cleanliness, S-safety, PS-physical segregation, ST-storage and transport, PL-packaging and labelling, EP-ethical practices, TP-training and personnel, IC-innovation capability, RA- resource availability

Fig 1: The final model of CFA first-order measurement model of HFSC implementation

For this study, model fitness for the first-order dimensions is checked by using several fitness indices: $\chi^{2} / d f, R M S E A, S R M R, G F I, C F I, A G F I, T L I$ and CFI. The fitness indices suggest an acceptable fit for the final first-order measurement model. The AGFI is close to 0.90 which are considered acceptable fit for the measurement model (Zhu et al., 2008). Furthermore, the $\chi^{2} / \mathrm{df}=1.65, \mathrm{GFI}=$ $0.90, \mathrm{CFI}=0.93, \mathrm{TLI}=0.94, \mathrm{SRMR}=0.05$ and $\mathrm{RMSEA}=0.05$ are within the acceptable threshold values (Chau and $\mathrm{Hu}, 2001$ ), thus indicates the significant fit for the first-order measurement model.

\section{Reliability and Validity of the Full Measurement Model}

Having an acceptable overall model fit, the next phase of confirmatory factor analysis (CFA) is to assess the psychometric properties of measures regarding reliability properties, construct validity, convergent validity, and discriminant validity. Reliability refers to the internal consistency of items that comprise a latent construct (Hair et al., 2010). The requirement of reliability can be checked through the process of internal reliability and construct reliability. The results reveal that Cronbach alpha coefficient scores range between 0.80 and 0.91 for all dimensions demonstrate a good level of internal consistency (Nunnally, 1978). Furthermore, the composite reliability of every dimensions for this study ranged from 0.79 to 0.91 , higher than the acceptable threshold value of 0.60 (Bagozzi and $\mathrm{Yi}, 1998)$. It concludes that measures used within this study were within the acceptable levels supporting the reliability of the dimensions.

Construct validity is the most important objective when evaluating a research measure (Bagozzi, 1980). In this study, all the fitness indices for the models were within the acceptable level and confirmed that construct validity is achieved based on the treshold by (Hsieh and Hiang, 2004). 
Convergent validity is assessed based on factor loadings and average variance extracted (AVE). According to Hair et al. (2010) and Awang (2015), convergent validity is reflected when standardised factor loadings exceeding 0.50, with statistical significance, and AVE is equal to or greater than 0.50. As an evidence of convergent validity, all factor loadings range from 0.60 to 0.93 were relatively high exceeding the critical value of 0.5 and statistically significant $(p<0.001)$. The results of AVE which value range from 0.53 to 0.77 also provide additional support for convergent validity. Therefore, the measures displayed adequate convergent validity.

Discriminant validity is demonstrated when each hypothesized construct is distinct from others and not measuring the same thing (Gallagher et al., 2008). As recommended by Kline (2010), the estimated correlations between latent constructs should not be higher than 0.85 . The results of inter-construct correlations were not excessively high which range from 0.11 to 0.77 (all are below 0.85 ) which demostrates that each constuct shares larger variance with its own measures than with other measures. Thus, discriminant validity is generally supported for all the constructs in the measurement model. Based on the results, we conclude that reliability and validity of the measurement models are assured.

\section{Assessment HFSC Implementation as a Higher-Order Construct}

The test is further assessed on the higher-order measurement model to confirm the HFSC implementation as a higher-order constructs. As shown in Figure 2, the measurement model-fit indices exceed common acceptance levels. The $\chi^{2} / \mathrm{df}$ for the model is $1.57 \leq 3.0$, suggesting that the measurement model is fitted to the sample data well. The value for GFI (0.90), CFI (0.95), TLI (0.94), and AGFI (0.84) is considered acceptable fit for the measurement model (Zhu et al., 2008). RMSEA and SRMR value are slightly increased from first-order measurement model to 0.06 and 0.07 respectively, suggesting acceptable fit. 
INTERNATIONAL JOURNAL OF ACADEMIC RESEARCH IN BUSINESS AND SOCIAL SCIENCES Vol. 8, No. 11, Nov, 2018, E-ISSN: 2222-6990 @ 2018 HRMARS

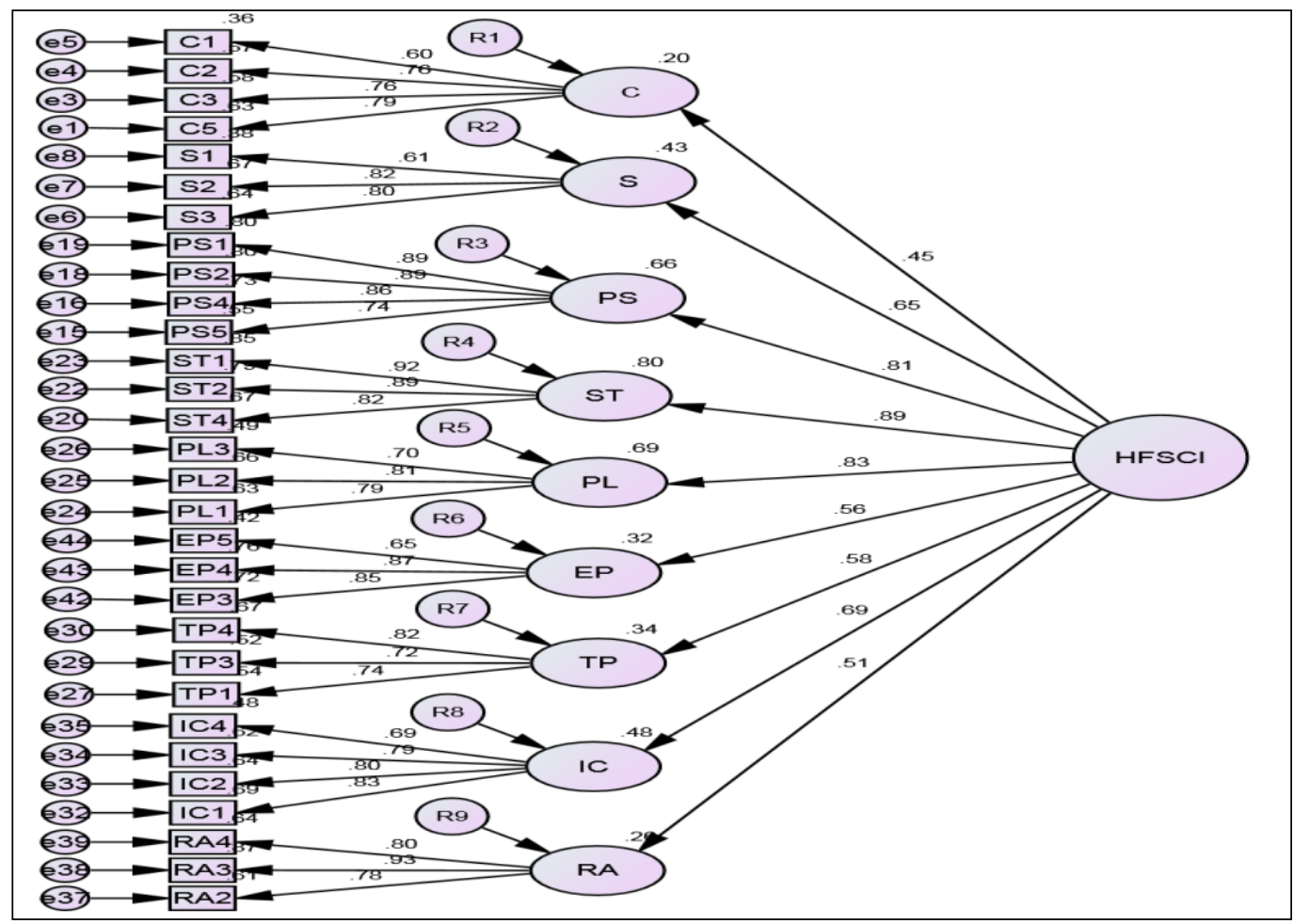

Notes: C-cleanliness, S-safety, PS-physical segregation, ST-storage and transport, PL-packaging and labelling, EP-ethical practices, TP-training and personnel, IC-innovation capability, and RA-resource availability

Fig 2: HFSC implementation as a higher-order construct

Furthermore, the higher-order standardised loadings on HFSC implementation model are 0.45 for $\mathrm{C}, 0.65$ for $\mathrm{S}, 0.81$ for PS, 0.89 for ST, 0.83 for PL, 0.56 for EP, 0.58 for TP, 0.69 for IC and 0.51 for RA. Furthermore, the findings reveal all paths are statistically significant $(p<0.01)$. The standardised estimates of all nine underlying first-order dimensions of HFSC implementation are found to be supported. HFSC implementation can then be acceptably conceptualised as a second-order unidimensional construct comprising of $C, S, P S, S T, P L, E P, T P, I C$ and RA. The analyses confirm that HFSC implementation as a second-order construct can be modelled.

\section{DISCUSSION}

This study is a first attempt toward providing a validated instrument for measuring the halal food supply chain (HFSC) implementation. Developing the measurement scale for this study involved an extensive review of halal food management and general food chains literature, face to face surveys, and the use of expert opinions. As a result, an instrument with 52 items measuring eleven dimensions of HFSC implementation was created. Then, the instrument is validated to assess the content validity and to check the consistency of the measurement items, directly provide a degree of confidence in the scales used.

Furthermore, to confirm the measurement model with underlying dimensions, confirmatory factor analysis (CFA) is used to test both first-order and higher-order measurement models. Both of the models are found to be acceptable fit, and the second-order models' paths are statistically 
significant. Therefore, this study provides concise HFSC implementation dimensions, and the model can be conceptualized as a higher-order multi-dimensional construct.

Based on the results, all the underlying dimensions were found to be important in defining this model. At the individual item, manufacturers might want to consider and give specific attention for each individual item and sub-dimensions once implementing HFSC. For example, the most important finding reveals that manufacturers should not ignore the importance of storage and transport, packaging and labelling and physical segregation throughout the supply chain process. Most importantly, organisations should provide separate processing lines for halal food production as part of HFSC implementation. For the improvement action, management team should be active enough to explore more innovative ideas on halal matters besides looking on improving the product design. Manufacturers need to have an improvement action where able in balancing all the elements of cleanliness and safety while implementing the HFSC. As for overall improvement, all nine dimensions are important to look at and additional focus would be on the critical ones.

Theoretically, this study has made a significant contribution by developing and validating the instrument for measuring halal food supply chain (HFSC) implementation. This study is the first attempt to develop and validate the measurement scale for the mentioned construct. The process of development and validation is adopted a comprehensive multi-step approach suggested by Shah and Ward (2007). Essentially, a pooled confirmatory factor analysis (CFA) was applied to assess the validation and model fit of a measurement model. This assessment considered as more extensive modelling of multivariate interrelations and allowing the output to be analysed in more precise manner, hence provides the new insights to the body of knowledge. Moreover, the validated measurement scale gives an opportunity to other academic to assess halal food supply chain studies using different theoretical domain.

\section{CONCLUSION}

The main contribution of this study is to propose a halal food supply chain (HFSC) implementation model with the intention to develop the underlying dimensions and validating the measurement items for HFSC implementation. Based on the overall findings, it can be suggested that the manufacturers should emphasise on the nine underlying dimensions which include cleanliness, safety, physical segregation, storage and transport, packaging and labelling, ethical practices, training and personnel, innovative capability and resource availability. Furthermore, the results provide valuable insights that can assist the managers in strengthening and improvise their strategies and capabilities particularly in the context of the halal food industry as to remain competitive in the market. However, this study was conducted in one single industry (processed food and beverage) in Malaysia. Hence, the results may not be generalised for other industry sectors within halal such as cosmetics and personal care, healthcare and pharmaceuticals.

In the future, research should reconsider applying the above model with the validated construct to other non-Muslim countries which may have a different culture background and halal food production regulations. The countries such as Australia, New Zealand, United States of America, Japan and United Kingdom could be potential non-Muslim countries to explore and compare with the current study. 
INTERNATIONAL JOURNAL OF ACADEMIC RESEARCH IN BUSINESS AND SOCIAL SCIENCES

Vol. 8, No. 11, Nov, 2018, E-ISSN: 2222-6990 @ 2018 HRMARS

\section{REFERENCES}

Ab Talib, M. S. \& Johan, M. R. M. (2012). Issues in halal packaging: a conceptual paper. International Business and Management, 5(2), 94-98.

Ab Talib, M. S., Hamid, A. B. A., Zulfakar, M. H., \& Jeeva, A. S. (2014). Halal logistics PEST Analysis: The Malaysia perspectives. Asian Social Science, 10(14), 119.

Abdul Rahim, A. (2005). A concept of the clean toilet from the Islamic perspective. Journal of Islam Built Environ, 1(1), 71-84.

Al-Qaradawi, Y. (2007). The Lawful and the prohibited in Islam. Kuala Lumpur: Islamic Book Trust. Ali, M. H., Tan, K. H., Pawar, K., \& Makhbul, Z. M. (2014). Extenuating food integrity risk through supply chain integration: the case of halal food. Industrial Engineering \& Management Systems, 13(2), 154-162.

Aung, M. M. \& Chang, Y. S. (2014). Traceability in a food supply chain: Safety and quality perspectives. Food control, 39, 172-184.

Awang, Z. (2015). SEM made simple: A gentle approach to learning Structural Equation Modeling. MPWS Rich Publication, Malaysia.

Bagozzi, R. P. (1980). Performance and satisfaction in an industrial sales force: An examination of their antecedents and simultaneity. the Journal of Marketing, 65-77.

Bagozzi, R. P., \& Yi, Y. (1988). On the evaluation of structural equation models. Journal of the academy of marketing science, 16(1), 74-94.

Bonne, K. \& Verbeke, W. (2008). Religious values informing halal meat production and the control and delivery of halal credence quality. Agriculture and Human Values, 25(1), 35-47.

Chau, P. Y. \& Hu, P. J. H. (2001). Information technology acceptance by individual professionals: A model comparison approach. Decision sciences, 32(4), 699-719.

Fadzlillah, N. A., Man, Y. B. C., Jamaludin, M. A., Rahman, S. A., \& Al-Kahtani, H. A. (2011). Halal food issues from Islamic and modern science perspectives. In International Conference on Humanities, Historical and Social Sciences. IACSIT Press, Singapore (Vol. 17, pp. 159-163). Gallagher, D., Ting, L., \& Palmer, A. (2008). A journey into the unknown; taking the fear out of structural equation modeling with AMOS for the first-time user. The Marketing Review, 8(3), 255275.

Hair, J. F. (2010). Black, WC, Babin, BJ, \& Anderson, RE (2010). Multivariate data analysis, 7th Edn. New Jersey: Prentice Hall.

Hsieh, Y. C., \& Hiang, S. T. (2004). A study of the impacts of service quality on relationship quality in search-experience-credence services. Total Quality Management \& Business Excellence, 15(1), 43-58.

Irfan, S. (2010). Consumer awareness: Thoughts and trends across the globe. Halal J, 2, 1011.

Jaques, T. (2015). Cadbury and pig DNA: when issue management intersects with religion. Corporate Communications: An International Journal, 20(4), 468-482.

Kline, R.B. (2010). Principles and Practice of Structural Equation Modeling. 3rd edn. New York: Guilford Press.

Lodhi, A-u-H. (2009). Understanding Halal Food Supply Chain. London: HFRC UK Ltd.

Mohd Albakir, S. N. W. S., \& Mohd-Mokhtar, R. (2011, May). A conceptual design of genuine 
INTERNATIONAL JOURNAL OF ACADEMIC RESEARCH IN BUSINESS AND SOCIAL SCIENCES

Vol. 8, No. 11, Nov, 2018, E-ISSN: 2222-6990 @ 2018 HRMARS

Halal logo detector. In Imaging Systems and Techniques (IST), 2011 IEEE International Conference on (pp. 296-301). IEEE.

Mohamad, A. B., \& Hassan, H. (2011). The influences of halal integrity on product adaptation strategy for global trade. International Business Management, 5(6 A), 421-426.

Nakyinsige, K., Man, Y. B. C., \& Sazili, A. Q. (2012). Halal authenticity issues in meat and meat products. Meat Science, 91(3), 207-214.

Netemeyer, R. G., Bearden, W. O., \& Sharma, S. (2003). Scaling procedures: Issues and applications. Sage Publications.

Norman, A. A., Md Nasir, M. H. N., \& Azmi, M. (2008). The users perceptions and opportunities in Malaysia in introducing RFID system for Halal food tracking. Computer Journal WSEAS Transactions on Information Science and Applications, 5(5), 843-852.

Nunnally, J.C. (1978). Psychometric Theory. 2 edn. New York: Mc Graw Hill. Nunnally, J.C. and Bernstein, I. (1994). The assessment of reliability. Psychometric Theory, 3, 248-292.

Omar, E. N., Jaafar, H. S. (2011). Halal transportation in the food industry - A conceptual model. IEEE Symposium on Business, Engineering and Industrial Applications (ISBEIA) (pp. $384-389$ ). Langkawi, Malaysia.

Riaz, M.N. and Chaudry, M.M. (2004). Halal Food Production. USA: CRC Press.

Shah, R., \& Ward, P. T. (2007). Defining and developing measures of lean production. Journal of operations management, 25(4), 785-805.

Shah Alam, S., \& Mohamed Sayuti, N. (2011). Applying the Theory of Planned Behavior (TPB) in halal food purchasing. International journal of Commerce and Management, 21(1), 8-20.

Soong, S. F., 2007. Managing halal quality in food service industry, Master Dissertation, University of Nevada., Las Vegas, USA

Standards Malaysia, 2009. Halal food-production, preparation, handling and storage general guidelines (second revision). MS 1500:2009, Malaysia.

Thomson Reuters. (2015). State of the Global Islamic Economy Report 2015-2016. 2015. Home. http://www.dinarstandard.com/state-of-the-global-islamic-economy-report-2015. Talib, H. H. A., Ali, K. M., Jamaludin, K. R., \& Rijal, K. (2008, May). Quality assurance in halal food manufacturing in Malaysia: A preliminary study. In Proceedings of International Conference on Mechanical \& Manufacturing Engineering (ICME2008) (pp. 21-23).

Tieman, M., van der Vorst, J. G., \& Che Ghazali, M. (2012). Principles in halal supply chain management. Journal of Islamic Marketing, 3(3), 217-243.

Tieman, M. (2011). The application of Halal in supply chain management: In-depth interviews. Journal of Islamic Marketing, 2(2), 86-195.

Wan Omar, W., Muhammad, M. Z., \& Omar, A. C. (2008, December). An analysis of the Muslim consumers'attitudes towards 'halal'food products in kelantan. In ECER regional conference (pp. 15-17).

Wan Omar, W. M., Rahman, S. \& Jie, F. (2015). Halal food chain management: A systematic review of literature and future research directions. Paper presented at 13th ANZAM Operations, Supply Chain and Services Management Symposium, Melbourne, Australia. 
Wilson, J. A., \& Liu, J. (2010). Shaping the halal into a brand?. Journal of Islamic Marketing, 1(2), 107-123.

Yang, Y., \& Bao, W. (2010, October). The design and implementation of halal beef wholly quality traceability system. In International Conference on Computer and Computing Technologies in Agriculture (pp. 464-472). Springer, Berlin, Heidelberg.

Zailani, S. H. B. D. M. (2010). Halal traceability and halal tracking systems in strengthening halal food supply chain for food industry in Malaysia. Journal of food Technology, 8(3), 74-81. Zhu, Q., Sarkis, J., \& Lai, K. H. (2008). Confirmation of a measurement model for green supply chain management practices implementation. International journal of production economics, 111(2), 261-273. 